\section{PROTEIN CRYSTALLIZATION FOR DRUG DESIGN IN THE LAST 50 YEARS}

\author{
Enrico A. Stura \\ CEA, iBiTec-S, SIMOPRO, France \\ estura@cea.fr
}

\begin{abstract}
Citation/Cómo citar este artículo: Stura, E. A. (2015). "Protein Crystallization for Drug Design in the Last 50 Years". Arbor, 191 (772): a222. doi: http://dx.doi.org/10.3989/
\end{abstract} arbor.2015.772n2008

Received: September 12, 2014. Accepted: February 13, 2015.

ABSTRACT: We live in an era where we expect to be able to visit our doctor and obtain a pill to cure any ailment from which we suffer. Yet, this is still not the case. Many of the current cures are still derived from natural sources although new drugs are increasingly the result of intelligent design. In this process, $\mathrm{X}$-ray protein crystallography now plays a major and effective role in the discovery of new treatments. The developments that have made this possible have evolved during the past fifty years. The methods for crystallizing macromolecules and determining their structures by X-ray crystallography have been automated and the speed for $X$ ray data acquisition is several orders of magnitude faster. Fifty years ago it took several years to solve a single structure. Now, several protein-ligand complexes can be determined in single day. High-throughput crystallography is considered to be a great asset to the drug discovery process, providing a fast way to tailor drug candidates to their targets by analysing their binding mode in detail. Crystallization remains the main challenge.

KEYWORDS: Drug design, crystallization.

\section{CRISTALIZACIÓN DE PROTEÍNAS EN EL DISEÑO DE FÁRMACOS EN LOS ÚLTIMOS 50 AÑOS}

Copyright: ( 92015 CSIC. This is an open-access article distributed under the terms of the Creative Commons Attribution-Non Commercial (by-nc) Spain 3.0 License.

RESUMEN: Vivimos en una época en la que esperamos ir al médico y obtener una pastilla para curar cualquier dolencia que padezcamos; por desgracia, esta expectativa no es real. Aunque muchos de los remedios en uso provienen de fuentes naturales, la mayoría de los nuevos medicamentos son el resultado de la investigación científica. En el proceso de diseño y descubrimiento de fármacos, la cristalografía de proteínas juega un papel central. Los conocimientos que han hecho esto posible han venido evolucionando desde hace cincuenta años aproximadamente. Los métodos de cristalización de macromoléculas y la determinación de sus estructuras a través de la cristalografía de rayos $\mathrm{X}$ han sido automatizados y miniaturizados y la velocidad de la adquisición de datos de difracción ha aumentado en varios órdenes de magnitud. Si hace cincuenta años la resolución de una sola estructura podría llevar varios años, actualmente se pueden determinar las estructuras de varios complejos proteína-ligando en un solo día. La cristalografía de alto rendimiento hoy día es un gran recurso en el proceso del descubrimiento de fármacos pues proporciona una manera rápida y precisa de adaptar los fármacos candidatos a las dianas mediante el análisis de su modo de unión. La cristalización sigue siendo el principal desafío.

PALABRAS CLAVE: diseño de fármacos, cristalización. 


\section{INTRODUCTION}

Protein crystallization pre-dates X-ray crystallography. Humans have practised this science since 1840 (Giegé, 2013), but other organisms have put protein crystallization to use much earlier. Bacillus thuringiensis, known for its insecticidal properties, produces protein crystals during sporulation. Fifty years ago the seminal ideas that would lead to modern protein crystallization methods were already in place and as it became understood that it was possible to visualize ligands in their binding sites, crystallographic pharmaceutical investigations started.

Protein crystals are themselves drugs (Figure 1). Insulin is important in the treatment of diabetes, and to slow down the release of this hormone it is delivered in crystalline form. NPH insulin, a suspension of crystalline zinc-insulin combined with a positively charged polypeptide, was created in 1936 by Nordisk, but the role of zinc, as an additive, to induce protein crystallization was not known until much later. The insulin crystal story began in 1934 when Dorothy Hodgkin was offered a small sample of crystalline insulin by Robert Robinson (Howard, 2003). Unfortunately, X-ray crystallography at that time could not cope with the complexity of the insulin molecule. She was able to grow better crystals by dialysing concentrated insulin against tap water (containing traces of zinc), but failed to do so with distilled water. The 3-dimensional structure of insulin was eventually determined by X-ray crystallography in her laboratory in 1969 (Crowfood and Riley, 1939). Zinc occupies the central position in a unit of six insulin molecules (hexamer). The insulin hexamer is not a crystallization artefact, but this is the form produced and stored in the body. It is inactive but has long-term stability. The monomer is the active form. The hexamer serves to keep the highly reactive monomeric insulin protected, yet available through hexamer-monomer conversion. Insulin can aggregate and form fibrillar interdigitated $\beta$-sheets. This can cause injection amyloidosis, and prevents the storage of insulin for long periods (Ivanova et al., 2009).

Figure 1. Crystals are drugs. Slow release insulin is designed with the addition of specific bulky hydrophobic groups. These insulin crystals are more stable. In addition to zinc stabilization (A), the covalently linked lithocholyl group form specific van der Waals and hydrogen-bonding interactions with neighbouring molecules (B) to strengthen the crystalline network and slow down dissolution of crystals. Lithocholic acid acylated insulin has affinity for circulating serum albumin to ensure slow absorption into the blood stream and prolongation of its half-life. The engineered insulin retains its affinity for its insulin receptor. (From PDB entry: 1UZ9; Whittingham et al., 2004).

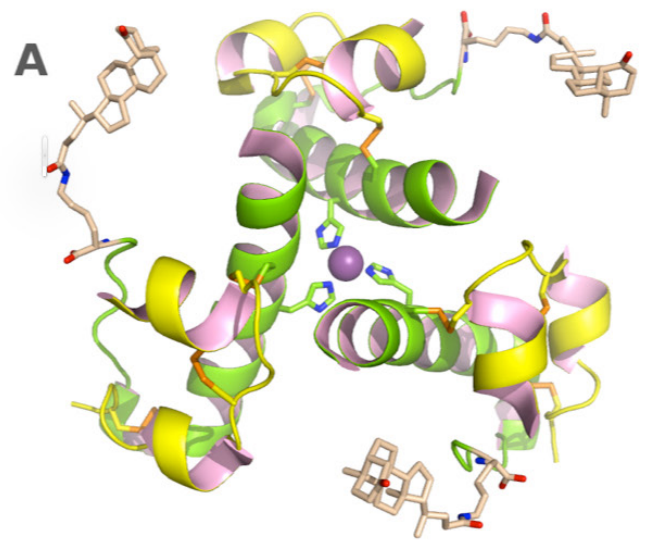

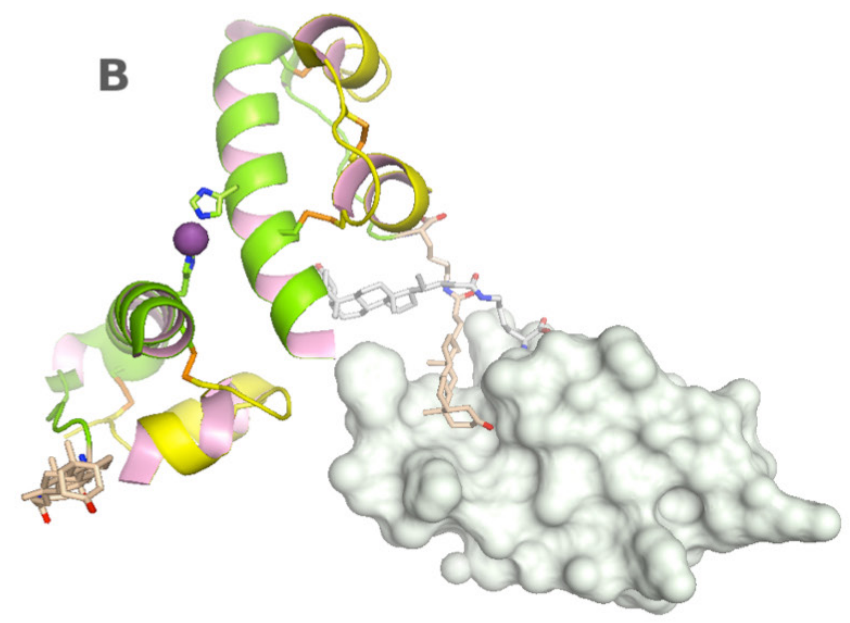


Amyloid fibril formation and deposition can lead to diseases, including spongiform encephalopathies, Alzheimer's and familial amyloidotic polyneuropathies. In familial amyloidotic polyneuropathy (FAP), the amyloid fibrils are mostly constituted by variants of transthyretin (TTR) (Quintas, Saraiva and Brito, 1997). Protein instability, leading to aggregation can be a problem in protein crystallization for X-ray crystallography, but not always. Transthyretin, previously known as prealbumin, is easily crystallized. The first crystals were obtained fifty years ago by Purdy et al. (1965) and by Haupt and Heide (1966) from 55\% saturated ammonium sulphate. The crystallization of insulin and transthyretin characterise the variation in solubility of proteins, with respect to the salt concentration in which they are bathed (salting-in/ salting-out). Transthyretin is a tetrameric protein in dynamic equilibrium with a monomeric form that, like insulin, has a tendency to aggregate. To prevent FAP, various potential inhibitors are being studied to understand the structure-activity relationship (SAR) (Nencetti and Orlandini, 2012). The relationship between the chemical or 3D structure of a molecule and its biological activity. The objective is to understand which chemical groups are responsible for its effect on the target protein. To achieve such an understanding, 222 transthyretin structures, from human and other species, complexed and uncomplexed have been deposited in the Protein Data Bank (PDB) (Berman et al., 2007). The inhibitors stabilize the tetrameric form shifting the equilibrium away from the amyloidogenic monomer.

Figure 2. Crystals and quaternary structure of transthyretin (TTR) a protein that transports thyroid hormones. The morphology of transthyretin crystals is highly variable although the arrangement of the molecules in the lattice remains constant $(\mathbf{A}-\mathbf{C})$. The crystals shape depends on the rate of growth of the crystals and not on the contacts that the molecules make with one another. Four TTR molecules form a tetramer (D) and the tetramer packs together with other tetramers always in the same manner. To reliably grow crystals streak seeding can be used. The crystals grow in a straight line (E) where the seeds have been deposited by the cat whisker. TTR is studied to develop amyloid inhibitors. Such inhibitor binds in the tetramer cavity in two independent binding sites (F). (From PDB entry: 4PM1; Ciccone et al., 2015).

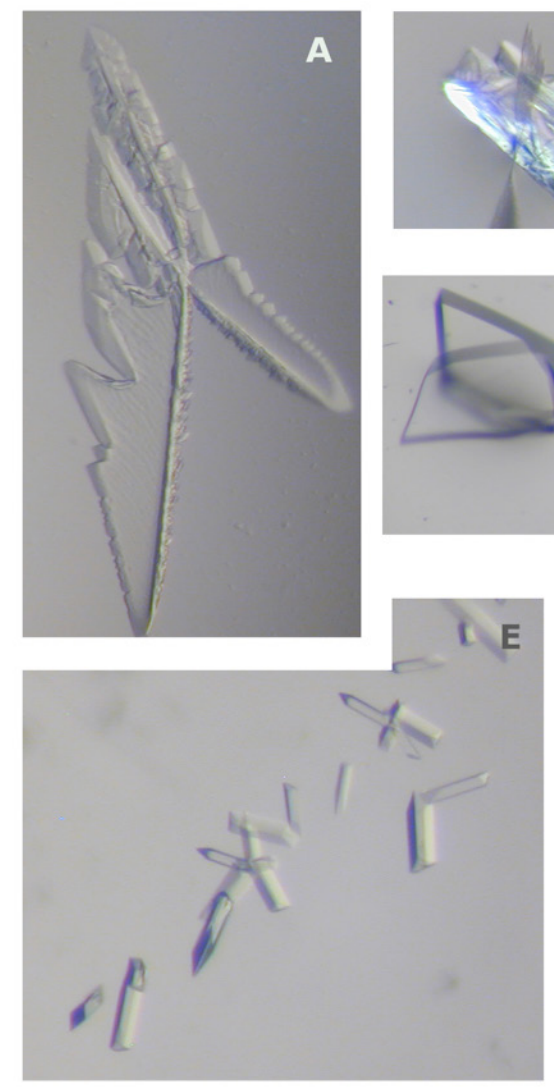

$\mathbf{B}$

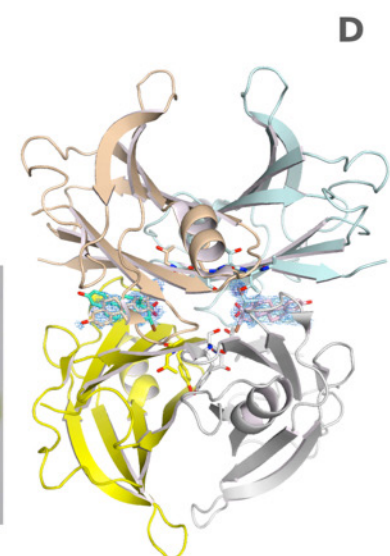

I E 
Protein solubility in water is highly variable and the salting-in/salting-out concept applies only to soluble proteins. Crambin, a polypeptide from the seeds of Crambe abyssinica, is not soluble in water. It was dissolved in ethanol and crystallized in 1965 by adding water. It is resistant to denaturing agents like $3 \mathrm{M}$ urea, and only partially affected by guanidinium: It showed some solubility in $8 \mathrm{M}$ guanidine hydrochloride (Teeter and Hendrickson, 1979). Urea and guanidine are now used to refold proteins expressed in Escherichia coli and found in inclusion bodies (Palmer and Wingfield, 2004), using similar concentrations of these agents. High-level expression of many recombinant proteins in Escherichia coli has revolutionized protein crystallization. Highly aggregated protein (inclusion bodies) are formed in the bacteria cytoplasm when high-level expression is induced. It is recovered from cell lysates by low speed centrifugation and the protein extracted from the washed pellets with guanidine $\cdot \mathrm{HCl}$ in a soluble but unfolded form that needs to be re-folded into its native and biologically active form. Currently the PDB contains 105,465 structures, of these 67,321 (64\%) were expressed in Escherichia coli. In the 1970s, insulin and recombinant DNA technology allows the birth of two biotech companies, Genentech and Biogen. The challenge is to insert the DNA sequence for human insulin into bacteria and let the bacteria produce the hormone.

The use of polyethylene glycol (PEG) to obtain crystals for X-ray data analysis starts in 1975 with deoxyhemoglobin crystals diffracting to $3.5 \AA$ A. Previously it had mainly been used for fractional precipitation (Ward et al., 1975). The steric exclusion mechanism of this precipitant was correctly identified as being similar to that of dextran reported by Torvard Laurent (Laurent, 1963). Size exclusion chromatography, using gels, typically made of dextran (Sephadex) and of other polymers, has become important as a protein purification method prior to crystallization. PEG is the single most successful precipitant, with currently 38,976 macromolecular structures deposited in the PDB.

While Genentech focuses mainly on proteins and antibodies as their products, Vertex Pharmaceuticals was founded in 1989 to pioneer an explicit strategy of rational drug design rather than combinatorial chemistry. The aim is to understand the molecular mechanisms of action of natural immunosuppressants, FK506 and rapamycin, that act on peptidyl proline isomerase FKBP. The successful structure determination of the FKBP/FK506/calcineurin complex encourages others to follow the pathway. Amgen, another biotechnology start-up focuses on erythropoietin (EPO), a glycoprotein hormone that controls red blood cell production. In 1998 they solve the structure of the EPO complex with the extracellular ligand-binding domain of its receptor (EPO binding protein EBP) (Syed et al., 1998), but they were preceded by a team at The Scripps Research Institute (TSRI). The TSRI team succeeds, two years earlier, to determine the structure of the complex between EBP and an EPO mimetic peptide (EMP) discovered by Affymax (Livnah et al., 1996). The synthetic peptide, attached to polyethylene glycol, is approved the FDA in 2012, and enters the market in 2013 , only to be recalled almost immediately, after 3 deaths, as $0.02 \%$ of patients suffer from severe hypersensitivity reactions. Successes dominate over failures. Structural studies have resulted in anti-HIV drugs that target the viral reverse transcriptase, integrase and protease; and anti-cancer drugs aimed at various tyrosine kinases.

\section{NATURAL DRUGS}

The immunosuppressant drug, rapamycin, produced by the bacterium Streptomyces hygroscopicus, and FK-506, produced by S. tsukubaensis, are used to prevent organ rejection in transplantation. Their action prevents activation of $\mathrm{T}$ cells and $\mathrm{B}$ cells by inhibiting the production of interleukin-2 (IL-2). FK506 gives the name to a family of FK-binding proteins (FKBP). FK-506 binds to FKBP12 thus reducing the peptidyl-prolyl isomerase activity of this immunophilin. Most crystals of FKBPs have been obtained only in complex with the immunosuppressant drugs.

In "The Billion Dollar Molecule: One Company's quest for the perfect drug", Barry Werth describes the first few years of Vertex in its quest to create drugs by rational drug design. Werth renders both the science and the intricacies of the business deals at Vertex. The narrative offers an insight at a critical moment in the history of science when under the impulse of Joshua Boger, a researcher that leaves Merck to found a new company, the focus of scientific research also shifts from screening soil samples and insect secretions to a new world where proteins and their inhibitor complexes can be crystallized and from their structure using computing power new drugs can be designed. The founding of Vertex's is vision- 
ary, but the idea that the new drugs would be without side effects because of the precision of the design, is still to be realised. The book describes Boger's first target molecule, FKBP, important in preventing the host's body from rejecting transplanted organs. The contrast between real science and the necessity of fund raising sees Boger going out to raise money, Vertex's researchers hunkered down in the laboratory benches to isolate and analyse FKBP, in a race against a tough team composed of Prof. Stuart L. Schreiber at Harvard and Manuel Navia, the crystallographer. Manuel's parents went to the U.S. from Cuba, worked really hard and a strong value system that he tried to emulate. The advantage of academic science, where collaborations are possible, contrasts with the world of business where scientists need to hide proprietary results instead of presenting them at conferences or publishing them open to the criticism of reviewers. The book is warmly recommended as a riveting tale of human endeavour that shows how scientific antagonism can drive discovery. In this historical review we are more concerned on how crystallization methods have evolved in the past 50 years than in discussing academic in contrast to industrial research.

In crystallization, the inhibitors, substrates, modulators and other ligands, be they other proteins or small-molecules are the most important consideration in crystallization (Dale, Oefner and D'Arcy, 2003). The various complexes have a different likelihood for crystallization and different complexes will be able to select a different polymorph (Vera et al., 2013) depending on how the ligand is able to change the properties of its target. One of the most fundamental changes that ligands can cause is the bringing together of more that one molecule, in a manner that does not occur spontaneously. Even single atoms, like zinc, in the case of insulin, can bring together six or more protein molecules. This has been recognized to be critical in the crystallization of insulin. A single atom, oxygen makes the difference between oxy- and deoxy- haemoglobin. When oxygen binds to the iron complexed at the centre of the plane of the porphyrin ring it causes the iron atom to move back. This triggers as series of cooperative changes that result in a large scale movement of the whole assembly of the four molecules that constitute the heamoglobin tetramer. The change in a single haemoglobin molecule is transmitted to the other three monomers in the tetramer, so that these too adopt a similar conformation in their hemes to facilitate the binding of oxygen to these sites. A cooperative process helps crystallization because all the molecules can shift in synchrony from one form to another, avoiding heterogeneity that would make crystallization more difficult. In absence of a cooperative process, heterogeneity is inevitable and the binding affinity of the ligand for the protein becomes important as it will determine how many of the protein molecules are complexed and how many are not. Higher affinity ligands ensure that a higher portion of the protein molecules will be complexes. For low affinity ligands the ligand is added in excess, up to ten times more compared to the protein. This strategy is not effective to crystallize complexes of two or more proteins. In my laboratory we have investigated the use of bifunctional inhibitors to bring together two proteases to change the manner in which crystallization occurs (Antoni et al., 2013).

Ideas that the use of PEG instead of salts like ammonium sulphate would help maintaining complexes have been abandoned as it has been realised that at high salt concentrations, AS is as effective as PEG.

\section{SYNTHETIC DRUGS}

Administration of folic acid (vitamin B9) worsens leukemia. This led to the development of folic acid analogues, including methotrexate (MTX), to inhibit folic acid metabolism. MTX is used in the treatment of cancer and autoimmune diseases. It acts by binding to dihydrofolate reductase (DHFR). MTX was originally synthesised by an Indian biochemist and in 1947. Sidney Farber and co-workers showed that the molecule could induce remission in children with acute lymphoblastic leukemia. The first crystal structures of DHFR with MTX were determined for bacterial enzymes in 1982. In 1989, the crystal structure of the chicken enzyme was solved and one year later the first complex of human DHFR with the folate and 5-deazafolate were solved. The first crystal structure of human DHFR with MTX was obtained six years later, in 1995 . The enzyme was a MTX-resistant mutant with a single point mutation in the drug binding pocket. The long delay between the demonstration of the effectiveness of the ligand and the first crystal structure of the human enzyme complex gives an idea of the difficulty of obtaining suitable crystals to carry out drug design. There was great interest in DHFR and MTX on behalf of pharmaceutical companies. The human DHFR-MTX structural studies saw the involvement of researchers from Gensia Pharmaceuticals. Agouron Pharma- 
ceuticals was founded in 1978 with the aim to find selective inhibititors for DHFR and thymidate synthetase (TS). Hoffmann-La Roche had interests in antibacterial agents that target bacterial dihydrofolate reductases. The difficulties associated with protein crystallization became evident. Dr. Villafranca from Agouron was a co-organizer of the fifth International Conference on the Crystallization of Biological Macromolecules (ICCBM-5) in San Diego, in 1993. Dr. D’Arcy from Hoffmann-La Roche was there too. The National Aeronautics and Space Administration (NASA), interested in crystallization in microgravity, was a sponsor of the meeting.

Growing crystals in space was impractical, and researchers believed that convection free systems could be developed to obtain the same effect on earth. A system where silica-gel methods can be used in both vapour diffusion sitting drop and liquid-liquid diffusion was proposed as an alternative to microgravity during the ICCBM- 5 conference by Bob Cudney (Cudney, Patel and McPherson, 1994). Bob Cudney is the current president of Hampton Research, a crystallization supply company. Until the introduction of gels, three classical crystallization methods had dominated the field. These were batch, dialysis and vapour diffusion. The major advances consisted in the miniaturization of each of these methods. In the batch method, the protein is mixed with the precipitant, nucleation takes place on mixing and the crystals are left to grow. By changing the temperature in a controlled manner, the degree of supersaturation can be changed. The miniaturization of this method, for crystallization under oil suitable for crystallization with the IMPAX robot made by Douglas Instruments, revived the method that was no longer used (Chayen, Shaw Steward and Baldock, 1994). A generalization of crystallization with oils was later proposed by Naomi Chayen during ICCBM-7 in Granada, Spain, in 1998 (Chayen, 1999). Dialysis was miniaturized more than forty years ago with microdots of 5-20 $\mu \mathrm{L}$ capacity made in plexiglas. New set-ups have been proposed using agarose gels to carry out dialysis experiments in capillaries (Thiessen, 1994). Dialysis and batch account for only 60 and 766 structures in the PDB, respectively, while vapour diffusion counts for 66,887 entries. José Antonio Gavira has promoted the use of free-interface diffusion (Otálora et al., 2009). Triana Science \& Technology, Granada, Spain markets a kit to use the technique. The method accounts for only 12 PDB database entries.

\section{DRUGS FROM STRUCTURAL STUDIES}

AIDS was first clinically observed in 1981 in the United States. In 1983, when the causative agent was identified the crystallization field was mature to face the challenge to design molecules for antiretroviral therapy.

The inhibition of the HIV viral protease is regarded as major success of structure-based drug design. The protease inhibitors are highly effective against the virus and since the 1990s have been a key component of anti-retroviral therapies for AIDS. Nelfinavir (Viracept) (Figure 3), a protease inhibitor, was developed by Agouron Pharmaceuticals as part of a joint venture with Eli Lilly and Company. Saquinavir was developed by Roche, Ritonavir (Norvir) by AbbVie, Inc. Other companies focused on inhibiting HIV's reverse transcriptase. AZT, a nucleoside-based thymidine-analogue inhibitor, works by selectively inhibiting transcription. Resistance against nucleotides developed, so non-nucleoside reverse-transcriptase inhibitors were developed. To improve the crystals of a clinically relevant double mutant HIV-1 of reverse transcriptase in complex with ATP and the non-nucleoside inhibitor HBY-097 (Das et al., 2007), streak seeding was used (Stura and Wilson, 1990). One of the problems with protein crystallization is that as the crystal growth conditions are optimized, nucleation can fail. Seeding is used to stimulate nucleation. Various seeding techniques can be used (Stura and Wilson, 1991). In microseeding crystals are added to the protein solution before full equilibration of the protein precipitant drop. This method can fail because the seeds dissolve or too many seeds are added. Macroseeding where large seeds are added after equilibration, solves both problems encountered with microseeding, but it is time consuming and manipulation errors can also lead to failure.

Streak seeding where crystals are taken from an existing crystal with a cat whisker and dispersed in a non-equilibrated or equilibrated experiment in straight line is fast. Since it is easily repeated if it fails, it is a practical method to find the best conditions to grow crystals. It can also be used to grow crystals in a space group different from that of the seed crystals. This application is called: epitaxial jumps (Stura, Charbonnier and Taussig, 1999). The field has still many challenges. Over $50 \%$ of all modern medicinal drug targets are membrane proteins, proteins that interact with biological membranes (Figure 4). 
Figure 3. From crystals to drugs. The path towards a drug starts with the conception of an inhibitor (A) which ignores the actual three dimensional structure of the compound once in the active site of the enzyme (B). Before arriving at a formulation for the patient (C) it passes through a crystal structure. The results are often shown in a simplified representation that shows only the secondary structure of the protein (D) and not all the atoms (E). HIV protease inhibitors, including Viracept, are one of the great successes of structure-based drug design. (From the PDB entry: 1OHR; Kaldor et al., 1997).

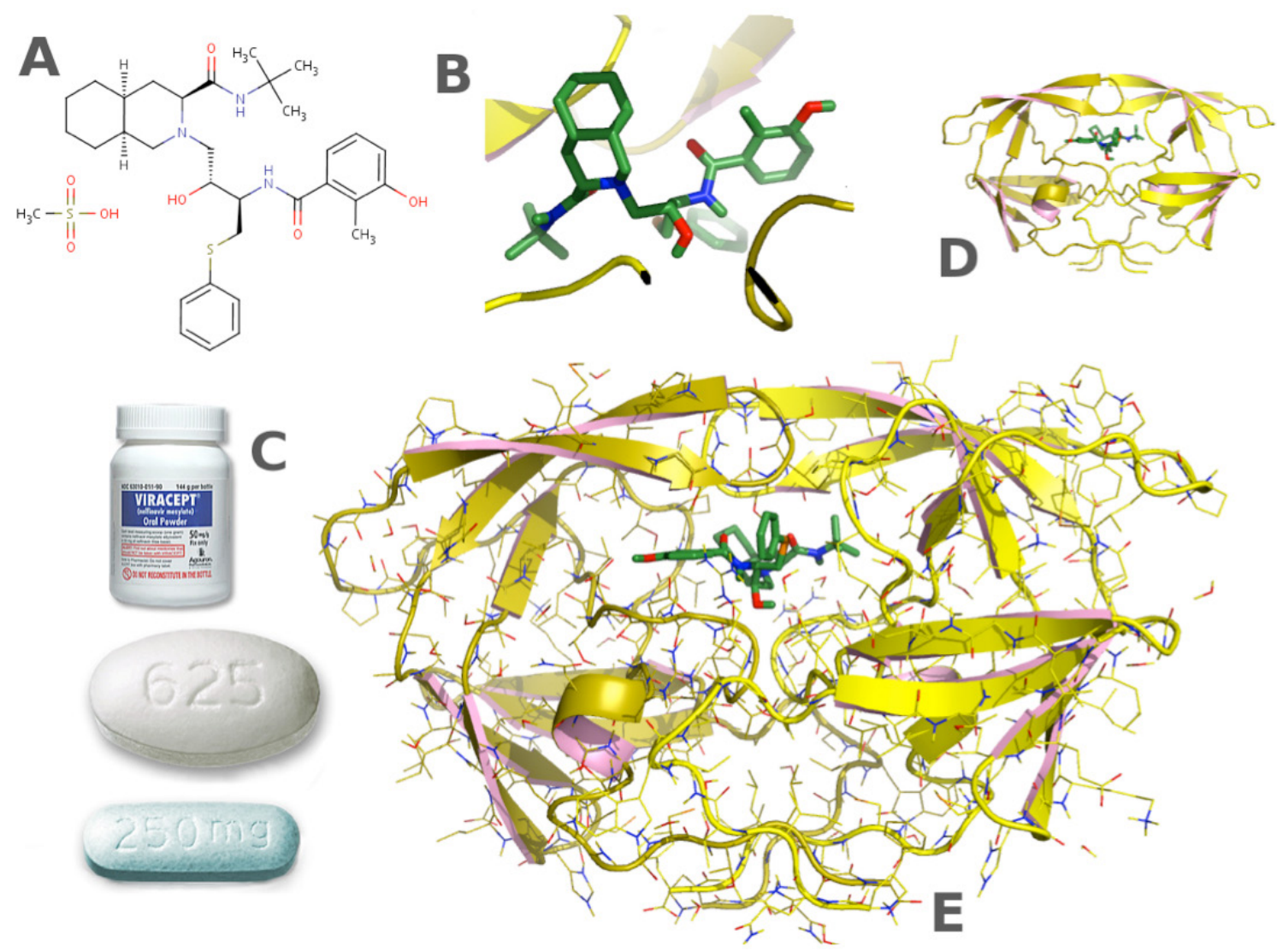

To crystallize these proteins, they must be extracted from the membrane using a detergent, and then the crystallization can proceed in a manner analogous to that used for soluble proteins. The problems arise when the protein is unhappy in the detergent. The in meso method for crystallizing membrane proteins is growing in popularity (Li et al., 2014).

The method involves both lipids and detergents. The lipids are manipulated to generate a continuous hard gel called lipid cubic phase (LCP). The protein solubilized in detergent is added to the LCP so that it can migrate into the lipid phase. The protein incorporated into the LCP is dispensed and used in crys- tallization experiments using the vapour diffusion technique as for soluble proteins. The method has increased the number of membrane proteins that have been crystallized.

Even if progress has been spectacular in the past fifty years, the rapid progress is likely to continue in the next fifty years. A crystal ball would be useful to predict the future of this science.

\section{ACKNOWLEDGEMENTS}

I am grateful to Natalia Stura for help with the Spanish abstract. 
Figure 4. Membrane proteins. Membrane proteins are important targets for drug design. G-protein-coupled receptors (GPCR) belong to the bateriorhodopsin (BR) family. They are of great interest to the pharmaceutical industry because they act as sensors to activate signal transduction pathways and cellular responses. Seven transmembrane helices characterize GPCR. BR was the first membrane protein to be crystallized. Initially as two dimensional crystals, but now after crystallization using lipidic cubic phases a three dimensional structure at atomic resolution has been determined. The transmembrane helices are surrounded by lipids (green) (A). In the centre there is a retinol (vitamin A) molecule (cyan). In mammals retinol is transported by retinol binding protein which in plasma is found complexed with transthyretin (C). (From PDB entries: 1C3W and 1QAB; Luecke et al., 1999; Naylor and Newcomer, 1999).

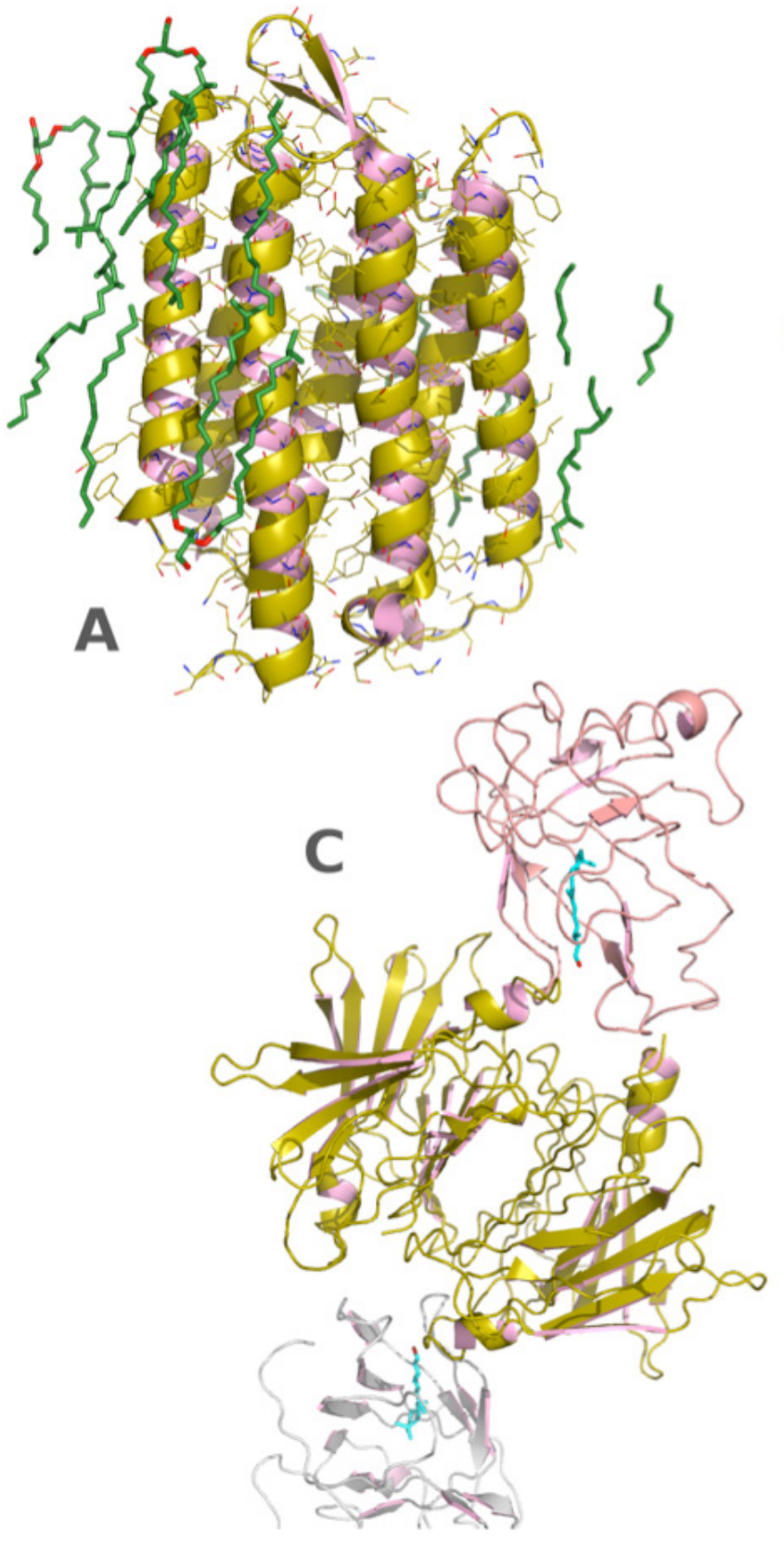

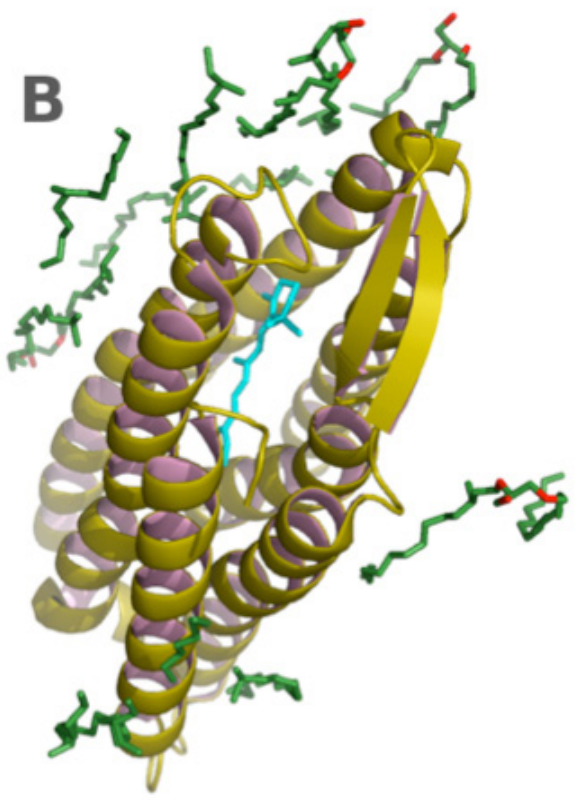




\section{REFERENCES}

Antoni, C., Vera, L., Devel, L., Catalani, M. P., Czarny, B., Cassar-Lajeunesse, E., Nuti, E., Rossello, A., Dive, V. and Stura, E. A. (2013). Crystallization of bi-functional ligand protein complexes. Journal of Structural Biology, 182, pp. 246-254. http://dx.doi.org/10.1016/j. jsb.2013.03.015

Berman, H., Henrick, K., Nakamura, H. and Markley, J. L. (2007). The worldwide Protein Data Bank (wwPDB): ensuring a single, uniform archive of PDB data. Nucleic Acids Research, 35, pp. D301D303. http://dx.doi.org/10.1093/nar/ gkl971

Chayen, N. E., Shaw Stewart, P. D. and Baldock, P. (1994). New developments of the IMPAX small-volume automated crystallization system. Acta Crystallographica, D50, pp. 456-458. http://dx.doi.org/10.1107/ S0907444993013320

Chayen, N. E. (1999). Crystallization with oils: a new dimension in macromolecular crystal growth. Journal of Crystal Growth, 196, pp. 434-441. http://dx.doi. org/10.1016/S00220248(98)008379

Ciccone, L., Tepshi, L., Nencetti, S. and Stura, E. A. (2015). Transthyretin complexes with curcumin and bromo-estradiol: evaluation of solubilizing multicomponent mixtures. New Biotechnology, 32, pp. 54-64. http://dx.doi.org/10.1016/j. nbt.2014.09.002

Crowfood, D. and Riley, D. (1939). X-Ray Measurements on Wet Insulin Crystals. Nature, 144, pp. 1011-1012. http:// dx.doi.org/10.1038/1441011a0

Cudney, R., Patel, S., and McPherson, A. (1994). Crystallization of macromolecules in silica gels. Acta Crystallographica, D50, pp. 479-483. http://dx.doi. org/10.1107/S090744499400274X

Dale, G. E., Oefner, C. and D’Arcy, A. (2003). The protein as a variable in protein crystallization. Journal of Structural Biology, 142, pp. 88-97. http://dx.doi. org/10.1016/S10478477(03)000418

Das, K., Sarafianos, S. G., Clark, A. D., Boyer, P. L. Hughes, S. H. and Arnold, E. (2007). Crystal structures of clinically relevant Lys103Asn/Tyr181Cys double mutant HIV-1 reverse transcriptase in complexes with ATP and non-nucleoside inhibitor HBY 097. Journal of Molecular Biology, 365, pp. 77-89. http://dx.doi. org/10.1016/j.jmb.2006.08.097
Giegé, R. (2013). A historical perspective on protein crystallization from 1840 to the present day. FEBS Journal, 280, pp. 6456 97. http://dx.doi.org/10.1111/febs.12580

Haupt, H. and Heide, K. (1966). Crystallization of prealbumin from human serum. Experientia, 22, pp. 449-451. http:// dx.doi.org/10.1007/BF01900976

Howard, J. A. K. (2003). Dorothy Hodgkin and her contributions to biochemistry. Nature Reviews Molecular Cell Biology, 4, pp. 891-896. http://dx.doi. org/10.1038/nrm1243

Ivanova, M. I., Sievers, S., Sawaya, M. R., Wall, J. S. and Eisenberg, D. (2009). Molecular basis for insulin fibril assembly. Proceedings of National Academy of Sciences of the USA, 106, pp. 18990-18995. http:// dx.doi.org/10.1073/pnas.0910080106

Kaldor, S. W., Kalish, V. J., Davies, J. F. 2nd. Shetty, B. V., Fritz, J. E., Appelt, K., Burgess, J. A.,, Campanale, K. M., Chirgadze, N. Y., Clawson, D. K., Dressman, B. A., Hatch, S. D., Khalil, D. A., Kosa, M. B., Lubbehusen, P. P., Muesing, M. A., Patick, A. K., Reich, S. H., Su, K. S. and Tatlock, J. H. (1997). Viracept (nelfinavir mesylate, AG1343): a potent, orally bioavailable inhibitor of HIV-1 protease. Journal of Medicinal Chemistry, 21, pp. 3979-3985. http://dx.doi.org/10.1021/ jm9704098

Laurent, T. C. (1963). The interaction between polysaccharides and other macromolecules. 5. The Solubility of Proteins in the presence of dextran. Biochemical Journal, 89, pp. 253-257.

Luecke, H., Schobert, B., Richter, H. T. Cartailler, J. P. and Lanyi, J. K. (1999). Structure of bacteriorhodopsin at 1.55 Å resolution. Journal of Molecular Biology, 291, pp. 899-911. http://dx.doi. org/10.1006/jmbi.1999.3027

Li, D., Howe, N., Dukkipati, A., Shah, S. T. A., Bax, B. D., Edge, C., Bridges, A., Hardwicke, P., Singh, O. M. P., Giblin, G., Pautsch, A., Pfau, R., Schnapp, G., Wang, M., Olieric, V. and Caffrey, M. (2014). Crystallizing Membrane Proteins in the Lipidic Mesophase. Experience with Human Prostaglandin E2 Synthase 1 and an Evolving Strategy. Crystal Growth \& Design, 14, pp. 2034-2047. http://dx.doi.org/10.1021/cg500157x

Livnah, O., Stura, E. A., Johnson, D. L., Middleton, S. A., Mulcahy, L. S., Wrighton, N. C., Dowr, W. J., Jolliffe, L. K. and Wil- son, I. A. (1996). Functional mimicry of a protein hormone by a peptide agonist: the EPO receptor complex at $2.8 \AA$. Science, 273, pp. 464-71. http://dx.doi. org/10.1126/science.273.5274.464

Naylor, H. M. and Newcomer, M. E. (1999). The structure of human retinol-binding protein (RBP) with its carrier protein transthyretin reveals an interaction with the carboxy terminus of RBP. Biochemistry, 38, pp. 2647-2653. http://dx.doi. org/10.1021/bi982291i

Nencetti, S. and Orlandini, E. (2012). TTR fibril formation inhibitors: is there a SAR? Current Medicinal Chemistry, 19, pp. 2356-2379. http://dx.doi. org/10.2174/092986712800269326

Otálora, F., Gavira, J. A., Ng, J. D., García-Ruiz, J. M. (2009). Counterdiffusion methods applied to protein crystallization. Progress in Biophysics and Molecular Biology, 101, pp. 26-37. http://dx.doi. org/10.1016/j.pbiomolbio.2009.12.004

Palmer, I. and Wingfield, P. T. (2004). Preparation and extraction of insoluble (inclusion-body) proteins from Escherichia coli. Current Protocols in Protein Science, Chapter 6, Unit 6.3. http://dx.doi. org/10.1002/0471140864.ps0603s38

Purdy, R. H., Woeber, K. H., Holloway, M. T. and Ingbar, S. H. (1965). Preparation of Crystalline Thyroxine-binding Prealbumin from Human Plasma. Biochemistry, 4, pp. 1888-1895. http://dx.doi. org/10.1021/bi00885a029

Quintas, A., Saraiva, M. J. and Brito, R. M. (1997). The amyloidogenic potential of transthyretin variants correlates with their tendency to aggregate in solution. FEBS Letters, 418, pp. 297-300. http://dx.doi.org/10.1016/ S00145793(97)013987

Stura, E. A. and Wilson, I. A. (1990). Analytical and production seeding techniques. Methods, 1, pp. 38-49. http://dx.doi. org/10.1016/S10462023(05)801458

Stura, E. A. and Wilson, I. A. (1991). Applications of the streak seeding technique in protein crystallization. Journal of Crystal Growth, 110, pp. 270-282. http://dx.doi. org/10.1016/00220248(91)90896D

Stura, E. A., Charbonnier, J. and Taussig, M. J. (1999). Epitaxial jumps. Journal of Crystal Growth, 196, pp. 250-260. http://dx.doi.org/10.1016/ S00220248(98)00832X 
Syed, R. S., Reid, S. W., Li, C., Cheetham, J. C., Aoki, K. H., Liu, B., Zhan, H., Osslund, T. D., Chirino, A. J., Zhang, J., FinerMoore, J., Elliot, S., Sitney, K., Katz, B. A., Matthews, D. J., Wendoloski, J. J., Egrie, J. and Stroud, R. M. (1998). Efficiency of signalling through cytokine receptors depends critically on receptor orientation. Nature, 395, pp. 511-516. http:// dx.doi.org/10.1038/26773

Teeter, M. M. and Hendrickson, W. A. (1979). Highly ordered crystals of the plant seed protein crambin. Journal of Molecular Biology, 127, pp. 219-223. http://dx.doi. org/10.1016/00222836(79)902420
Thiessen, K. J. (1994). The use of two novel methods to grow protein crystals by microdialysis and vapor diffusion in an agarose gel. Acta Crystallographica, D50, pp. 491-495. http://dx.doi. org/10.1107/S0907444994001332

Vera, L., Antoni, C., Devel, L., Czarny, B., Cassar-Lajeunesse, E., Rossello, A., Dive, V. and Stura, E. (2013). Screening Using Polymorphs for the Crystallization of Protein-Ligand Complexes. Crystal Growth \& Design, 13, pp. 1878-1888. http://dx.doi.org/10.1021/cg301537n

Ward, K. B., Wishner, B. C., Lattman, E. E. and Love, W. E. (1975). Structure of deoxyhemoglobin a crystals grown from polyethylene glycol solutions. Journal of Molecular Biology, 98, pp. 161-177. http://dx.doi.org/10.1016/ S00222836(75)801070

Whittingham, J. L., Jonassen, I., Havelund, S., Roberts S. M., Dodson E. J., Verma C. S., Wilkinson A. J. and Dodson G. G. (2004). Crystallographic and solution studies of $\mathrm{N}$-lithocholyl insulin: a new generation of prolonged-acting human insulins. Biochemistry, 25, pp. 5987-5995. http://dx.doi.org/10.1021/ bi036163s 